\title{
The Resilience Strategies of the Elderly Living in Villages; How Does the Government Contribute to their Well-being and Livelihood?
}

\author{
Yasnita Yasnita ${ }^{1}$, Fauzi Abdillah ${ }^{2}$ \\ \{yasnita@unj.ac.id¹, abdillah@unj.ac.id²\} \\ Universitas Negeri Jakarta, Jakarta, Indonesia
}

\begin{abstract}
The physical and psychological infirmities have prevented the elderly to work productively. However, under such conditions, in some villages in Indonesia, many of them are forced to work to feed themselves. This research aimed to investigate the elderly resilience strategies to support their well-being and how the government contributes to their livelihood. As the research focused on the elderly real-life experiences, qualitative research was conducted with phenomenology as the research approach. To collect the data, three research instruments were utilized: survey, interview, and observation toward 20 elder people from Bantarjati village, Bogor, West Java. The survey was utilized to collect the data of the 20 participants while the interview was employed to gain in-depth information about the participants' life and their resilience. The observation was conducted to confirm and check the data validity. To analyses the survival aspects, Li and Ow's (2021) four constructs: personal strength, meaning and purpose of life, family support, and social support were used, and Miles \& Huberman's model for the data analysis. The research found that family and social supports were the main factors to sustain the elderly survival. The elderly resilience strategies were living with their families and strengthening relationships and ties with their social milieu. This study also revealed that the government's contribution to support the elderly was nonexistence; They only provided healthcare and social security agency facilities to the 10 participants. The research concluded that families and relatives' supports and social relationships were the two aspects that became vital factors to the well-being and survival of the elderly.
\end{abstract}

Keywords: The Elderly; Resilience Strategies; The Government Contribution

\section{Introduction}

The Central Bureau of Statistics (BPS) mentioned that the total population of elder people in Indonesia was around $9,78 \%$ of the total population or 25.406 .000 people in 2020 (BPS,2021). It is predicted that the number will experience a gradual rise, and by 2045, the total number of the elderly will have peaked at $19,7 \%$ (Bappenas). The elderly are considered an inclusive group population owing to their physical and psychological conditions as well as 
social problems. These conditions deteriorate their anxiety, stress, and depression. In 2017, Lyons et al. (2018) conducted a national survey in Australia with 2137 elder people. They reported that the elderly suffered mental illness such as stress, anxiety, and depression. Similarly, Yasinta et al. (2020) found that the elderly tended to experience ageism and be ostracized due to their weak physical endurance. Even though becoming older is a natural life cycle, the acceptance of being old needs mental preparation. The aging process will significantly affect and change one's aspects of life. Potter and Perry (2005) identified three aspects that are considerably affected due to the aging process viz. physiology, psychosocial attitude, and cognitive. To face the aging process, people must be ready and have a high level of perseverance to accomplish successful aging.

Successful aging is defined as a condition in which one who enters their golden age still actively engages in life and has a high level of acceptance and happiness. To reach this quality of aging, mental readiness to accept the changes of the life aspects is needed. Potter and Perry (2005) stated that there are there three changes in people's aging process: physiological changes, psychosocial attitude changes, and cognitive changes. Failure in accepting these changes will result in stress and depression. If people are able to carry on with their old days successfully, they will be physiologically and psychologically independent and reduce their dependency on their younger generations. Successful aging becomes one of the main focuses in the field of human longevity owing to the rise of elder people's dependency. It is forecasted that in Indonesia the rate of elderly dependency will reach 33\% in the following 25 years (Ministry of Social Affairs of the Republic of Indonesia). To reduce the dependency ratio, the elderly need to have survival strategies. This research will study deeply the resilience strategies of the elderly in Bantarjati village.

Bantarjati is a village located in the regency of Bogor. Even though its location is near the capital city of Indonesia, Jakarta, the people of Bantarhati are categorized into a traditional and simple society. Most of the people work at factories in Cibinong, the biggest regency of Bogor, and its vicinity. Few numbers of them are still a small farmer, and oftentimes they consume their own harvests. To struggle in their life and overcome their physical and psychical feebleness due to the aging process, the elderly are forced to have resilience strategies. The strategies show the elderly's efforts to continue their life as happy and successful old people. So how can the elderly survive? Fontes dan Neri (2015) stated that the elderly's survival is dependent on the psychological resources and emotional regulations. It means that the elderly will survive if they are able to manage their emotion. They have to accept their condition, even though they are ignored. Southwick et al (2014) argued that the elderly's survival is the outcome of the complex constructions that can be defined differently in the contexts of individual, family, organization, society, and culture. Furthermore, Macleod et al. (2016) concluded that elder people have high survival level skills, despite their socioeconomic conditions, individual experience, and health factors. The findings of the abovementioned research pose several questions and challenges. The definition of survival formulated by Southwick et al. (2014) for example, poses some questions such as what are the determinant factors of elderly resilience? And how to improve resilience? Those questions need to be explored and investigated in the research to find conclusive and satisfying answers to the questions. To guide this research, the four constructs formulated by $\mathrm{Li}$ and $\mathrm{Ow}$ (2021) will be used. The constructs involve personal strength, meaning and purpose of life, family support, and social support.

This research also analyzed the government's contribution to the elderly well-being and livelihood. How does the government guarantee the elder citizen? Does the government give social aids, healthcare services, and other facilities that can be accessed by an elder citizen? 
These aspects can complete the elderly resilient conceptualizations that generate a comprehensive recommendation that can be used as a foundation to create policies on longevity that are in the elderly's favor. The findings of the research can also generate best practices that can be conceptualized into some field studies and be used as a basis for the government's decision-making, especially the policymakers in the field of longevity.

This research employed a qualitative method. As the main focus of the research is the exploration and investigation of real individual experiences, phenomenology is used as the research approach. The data were collected through survey, interview, and observation. To guide the research, four constructs formulated by $\mathrm{Li}$ and $\mathrm{Ow}$ (2021) will be used, the four constructs are personal strength, meaning and purpose of life, family support, and social support. The primary data were obtained through in-depth interview and observation. The secondary data were collected from survey results toward the elderly, especially on the aspects of the elderly's profile. There were 20 participants, and they were from three different villages located in the regency of Bogor viz. Nambo, Kopo, dan Bantarjati. The participants were female and male, chosen randomly, and were assumed to give information in line with research objectives. The survey data were analyzed quantitatively to complement the qualitative data to generate more comprehensive results. Then, the results were interpreted using Miles and Huberman analysis model and confirmed with the previous research findings and the relevant theories. The table below shows the research data:

Table 1. Objectives, Variables, Data, Data Collection Techniques and Data Analysis

\begin{tabular}{|c|c|c|c|c|}
\hline Objectives & Variable & 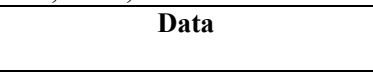 & $\begin{array}{l}\text { Data Collection } \\
\text { Techniques }\end{array}$ & Data Analysis \\
\hline $\begin{array}{l}\text { Participant's } \\
\text { information }\end{array}$ & $\begin{array}{l}\text { Personal } \\
\text { Information }\end{array}$ & $\begin{array}{l}\text { Age/Gender/Education } \\
\text { Occupation/ } \\
\text { Address/Livelihood/ } \\
\text { Social Aids/ } \\
\text { Health Insurance }\end{array}$ & Survey & Quantitative \\
\hline \multirow[t]{4}{*}{ Resilience } & Personal Strength & $\begin{array}{l}\text { Attitude, } \\
\text { Acceptance, } \\
\text { Physical Strength }\end{array}$ & Interview & Qualitative \\
\hline & $\begin{array}{l}\text { Meaning and } \\
\text { Purpose of Life }\end{array}$ & $\begin{array}{l}\text { Making sense of being old } \\
\text { Feeling } \\
\text { How to respond or deal with } \\
\text { the environment }\end{array}$ & $\begin{array}{l}\text { Observation } \\
\text { Interview }\end{array}$ & Qualitative \\
\hline & Family Support & $\begin{array}{l}\text { Son and/or daughter's attitude } \\
\text { dan mate } \\
\text { Family's care }\end{array}$ & Interview & Qualitative \\
\hline & Social Support & $\begin{array}{l}\text { Society's attitude } \\
\text { Neighbors dan relatives' care } \\
\text { Social relations and links }\end{array}$ & $\begin{array}{l}\text { Interview and } \\
\text { Observation }\end{array}$ & Qualitative \\
\hline \multirow[t]{2}{*}{ Strategies } & $\begin{array}{l}\text { Working } \\
\text { Living } \\
\text { children }\end{array}$ & $\begin{array}{l}\text { Economic activities } \\
\text { With whom do you live? }\end{array}$ & $\begin{array}{l}\text { Survey } \\
\text { Interview } \\
\text { Observation }\end{array}$ & $\begin{array}{l}\text { Quantitative } \\
\text { Qualitative and } \\
\text { Quantitative }\end{array}$ \\
\hline & Be Independent & $\begin{array}{l}\text { How to fulfill daily needs and } \\
\text { accommodation }\end{array}$ & & \\
\hline \multirow[t]{2}{*}{$\begin{array}{l}\text { Government's } \\
\text { Contributions }\end{array}$} & Social Aids & $\begin{array}{l}\text { Direct Cash } \\
\text { Groceries }\end{array}$ & Interview & Qualitative \\
\hline & Health Insurance & BPJS & survey & \\
\hline
\end{tabular}




\section{Results and Discussions}

\subsection{Results}

The data analysis findings, after they were collected through survey, interview with the participants with the age range from 65 to 100 years, and from three different villages in Bantarjati Village in the area of Klapanunggal as well as observation of the participants' life, are shown in the table below.

Table.2. The Research Results

\begin{tabular}{|c|c|}
\hline Aspects & Research Results \\
\hline \multicolumn{2}{|l|}{ Participants' information } \\
\hline Age & $65-100$ years old \\
\hline Education & $\begin{array}{l}2 \text { people are graduated from their primary school. } \\
18 \text { people do not have formal education. }\end{array}$ \\
\hline Occupation & $\begin{array}{l}4 \text { people work as a labour /a small-scale seller. } \\
16 \text { people are jobless. }\end{array}$ \\
\hline Accommodation & $\begin{array}{l}2 \text { people live on their own. } \\
18 \text { people live with their son or daughter (their son or daughter live with } \\
\text { them) }\end{array}$ \\
\hline Healthcare Insurance & $\begin{array}{l}10 \text { people have BPJS } \\
10 \text { do not have BPJS }\end{array}$ \\
\hline \multicolumn{2}{|l|}{ Resilience } \\
\hline Personal Strength & $\begin{array}{l}\text { The participants generally stated that they suffer health problems. } \\
\text { However, their acceptance of their conditions makes them strong. The } \\
\text { participants also surrender their life to God and accept their fate sincerely. }\end{array}$ \\
\hline $\begin{array}{l}\text { Meaning and Purpose } \\
\text { of Life }\end{array}$ & $\begin{array}{l}\text { Life is trust, the purpose of life is to continue the family line and pray to } \\
\text { God. } \\
\text { Although they were being sick and suffered from diseases, they accepted } \\
\text { their conditions sincerely. }\end{array}$ \\
\hline Family Support & $\begin{array}{l}\text { Son or Daughters, mates, and some relatives give supports to the } \\
\text { participants (offering food and giving care) }\end{array}$ \\
\hline Social Support & $\begin{array}{l}\text { The society give social aids or involve them in religious activities (17 } \\
\text { people) } \\
\text { ( } 3 \text { people shun their social surroundings- they are newcomers) } \\
\text { In their social interaction, they will ignore what people say about them. }\end{array}$ \\
\hline \multicolumn{2}{|l|}{ Daily needs } \\
\hline Fulfilling Daily Needs & $\begin{array}{l}\text { From their sons or daughters and other families } \\
\text { Work as a labour } \\
\text { Small-scale sellers }\end{array}$ \\
\hline \multicolumn{2}{|c|}{ Government's Contributions } \\
\hline Social Aids & $\begin{array}{l}\text { Rare } \\
\text { Only for prioritized group of people }\end{array}$ \\
\hline Healthcare Assurance & $\begin{array}{l}10 \text { people have BPJS } \\
10 \text { people do not have BPJS }\end{array}$ \\
\hline
\end{tabular}




\subsection{Discussions}

\subsubsection{Factors that determine the elderly resilience}

The Bantarjati people are traditional and relatively homogenous. The marriage system is endogamy, and they have strong ties and bonds with families and relatives. This impacts the pattern of elderly housing. As a collectivist society, after their marriage, they will stay and live with their parents or build a house near their parent's house. According to the Central Bureau of Statistics (2017) study in Mataram, Surabaya, and Medan, 15\% of the elderly people lived independently, $14 \%$ of the total population with their mate, $28 \%$ with their first generation. The $43,75 \%$ of the population lived with their second generation and the remaining $5 \%$ lived with their relatives

In Bantarjati village, a family or a social environment comprises of 3 to 4 generations. It is very common to meet grandmother, grandfather, father, mother, son, daughter, grandchildren, or even great-grandchildren in one house. When the son and/or daughter were small, the parents would tend their children, and when they grew up and became mature, they would take care of their parents instead.

The Bantarjati people have a relatively long life expectancy. The youngest participant is 65 years old (1 person), and the oldest is up to 100 years old. The average life of the participants is around 80 years old. This phenomenon might raise questions: how do the participants have a longer life? And how do they survive in continuing their life? The table below is the Li and Ow four constructs that guide the research to investigate the concept of elderly resilience:

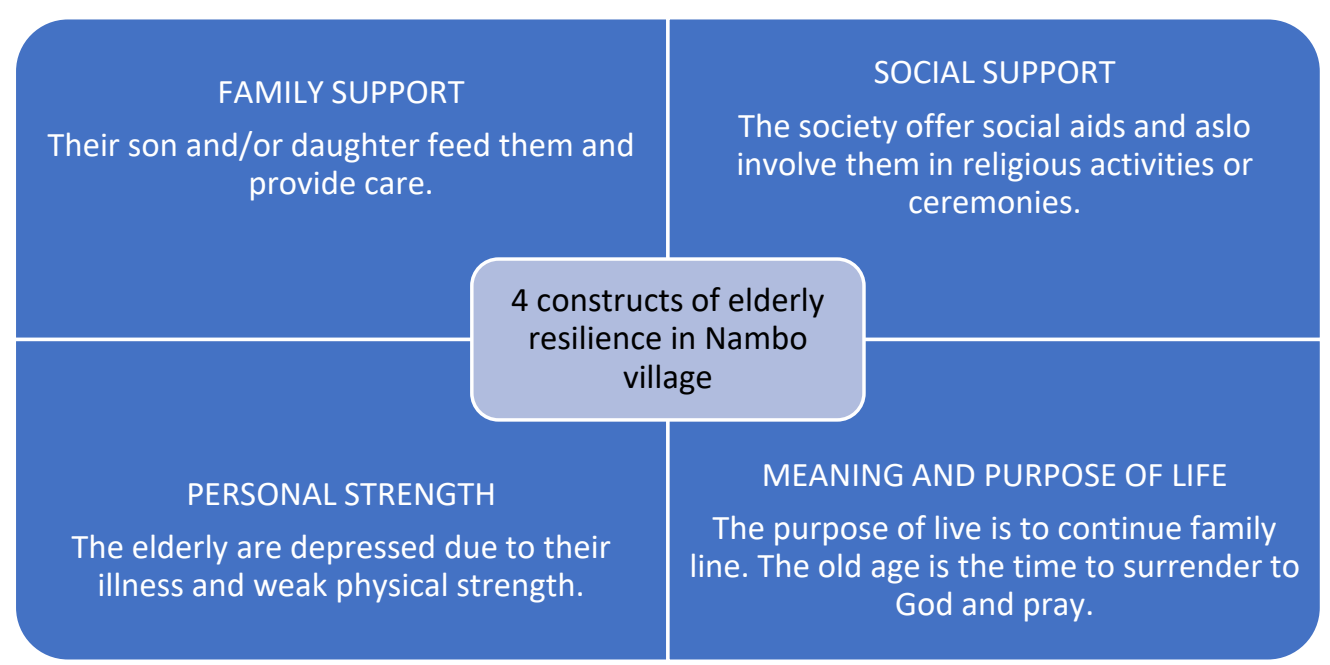

Fig. 1. The constructs of elderly resilience in Nambo village

Individually, the participants stated that they had grievances and felt depressed about their physical condition. Their bodies were becoming infirm and feeble. They also suffered from an illness that restricted their activities. Some of the participants were hard workers at a young age. In their old time, it is very difficult to work and fulfill their daily needs. However, the participants felt that the supports from their family, relatives, and neighbors encouraged them to survive and be stronger. 
This showed that the dominant factors determining elderly resilience are family and social supports. These supports make the elderly survive, and their life has become more meaningful. Consequently, the physical conditions are improved. Some of the participants even said that they could and must survive because of their families. These findings answered Southwick's (2014) questions about the determinant factors of elderly resilience. On the other hand, according to the observation results, the three participants were shunned from their social milieu. They were not comfortable with the social situation and avoided interacting with their neighbors. Further investigation revealed that they were newcomers. This is one of the problems living in a homogenous society.

In the context of making sense and meaning of life, participants believed that having sons and daughters who will continue their legacies and pray to God are the main purposes of life. The infirm and weak body is not a burden. The old-time is the time to do good things and uphold religious values. Even they suffer from their weakness and feebleness, they believe that in the hereafter they will find ultimate peace.

\subsubsection{The Fulfillment of Daily Needs}

With their weak physical and psychological conditions, the old people may not be able to fulfill their basic needs. Four participants stated that they have to work because their sons and/or daughters are unable to help and feed them. Although their physical conditions are weakened, they become a peddler or labor to support their well-being. As for the 16 participants, they acknowledged that they were unable to work due to their physical conditions. To sustain their life, they are dependent on their families, relatives, and neighbors. This situation supports Yasnita's (2019) findings that the fulfillment of daily needs was based on their pension, their selling, family's assistance, social aids, or other contributions.

\subsubsection{The Government's Contribution to the Elderly Resilience}

The government of the Republic of Indonesia constitutionally respects the older people. The 1945 Constitution of the Republic of Indonesia article 27 verse 2 stated "[e]very citizen shall be entitled to work and a living that is decent for humanity", and in article 34 verse 2 mentioned, "[t]he state shall develop a social security system for all the people and empower the poor and incapable society in accordance with human dignity." Moreover, the Indonesian government has specifically passed the law in Constitutions Number 13 the Year 1998 on the prosperity and the welfare of the elderly. The law addresses healthcare insurance for the elderly through BPJS, the elderly accessibility to utilize the public facilities and other social aids such as direct cash and basic needs.

Yasnita's (2019) study found best practices in the 3 largest cities in Indonesia: Jakarta, Bandung, and Yogjakarta. In Jakarta, the government distributed Kartu Lansia Jakarta (KLJ), a financial assistance program for the elderly. The program gives a monthly incentive of IDR 600.000 for the elderly. The Social Department of DKI Jakarta conducted assessments for the elderly before they obtained financial assistance. In the city of Bandung, the Social Department distributed 661 daily needs packages and incentive IDR 200.000 to the displaced elderly. In Yogjakarta, financial support was also given. The poor and displaced elderly were given IDR 150.000 monthly by the government.

Ironically, such incentives and assistance were non-existence in Bantarjati village. The elderly stated that the government contributions and aids to sustain their life were rare. Some of the participants said that only once did they received government social assistance. The 
participants mentioned that the government did not intend to assist their livelihood. Most of the assistance were from their relatives, neighbors, or the philanthropist. As for the healthcare assurance, only 10 participants had BPJS facility. These conditions and situations indicated that the government's contribution to the elderly resilience in Bantarjati village, the regency of Bogor was lacking.

\subsubsection{Elderly Resilience Strategies in Bantarjati Village, the Regency of Bogor}

This subchapter answers the question: how do the elderly sustain their well-being and livelihood? Fontes and Neri (2015) stated that elderly resilience is dependent on psychological resources and emotional regulations. It means that elderly livelihood will be sustained if they are able to manage their emotions. This research found similar findings. Even though the Bantarjati elder people suffered from infirmities and weakened physical conditions, they were able to manage their emotions and psychology so that they could accept their condition. Family and social environment assistance and support are the panaceas of their feebleness and physical debilities. This research also found that they had mental acceptance of their conditions even though they were ignored by their social surroundings. Southwick et al. (2014) stated that elderly resilience is the outcome of complex constructions that can be defined differently in the contexts of individuals, families, organizations, societies, and cultures. Furthermore, Macleod et al. (2016) concluded that elder people have high survival level skills, despite their socio-economic conditions, individual experience, and health factors. The resilience of elder people is affected by family support factors and social support. Thus, to be able to sustain their life, the elderly have three strategies namely living with their family (family support), the ability to manage emotions, and strengthen social ties (social support).

\section{Conclusion}

Family support, social support, and the ability to manage emotions are the three vital factors that contribute to the elderly resilience to accomplish successful aging. Meanwhile, government supports are not a significant factor. Thus, to sustain and continue their life, the elderly need to strengthen their relationship with their family and social surroundings.

\section{Acknowledgment}

This research would not have finished without the contributions of others. Special thanks to the Faculty of Social Science, Jakarta State University for funding this research. I am particularly grateful to the 20 participants.

\section{References}

[1] Fontes, A. P., \& Neri, A. L. (2015). Resilience in aging: Literature review. Ciência \& Saúde Coletiva, 20(5), 1475-1495. https://doi.org/10.1590/141381232015205.00502014

[2] Li, Y.-T., \& Ow, Y. S. Y. (2021). Development of resilience scale for older adults. Aging \& Mental Health, 1-10. https://doi.org/10.1080/13607863.2020.1861212 
[3] Lyons, A., Alba, B., Heywood, W., Fileborn, B., Minichiello, V., Barrett, C., Hinchliff, S.,Malta, S., \& Dow, B. (2018). Experiences of ageism and the mental health of older adults. Aging \& Mental Health, 22(11), 1456-1464. https://doi.org/10.1080/13607863.2017.1364347

[4] MacLeod, S., Musich, S., Hawkins, K., Alsgaard, K., \& Wicker, E. R. (2016). The impact of resilience among older adults. Geriatric Nursing, 37(4), 266-272. https://doi.org/10.1016/j.gerinurse.2016.02.014

[5] Potter, P. A., \& Perry, A. G. (2005). Buku ajar fundamental keperawatan: Konsep, proses, dan praktik (Edisi 4 Volume 1). Jakarta: Penerbit Buku Kedokteran EGC.

[6] Santika, Adi.,dkk.2020. Lansia dari Kalangan Minoritas dan Rentan. Jakarta: Ragam Institute. 2020

[7] Southwick, S. M., Bonanno, G. A., Masten, A. S., Panter-Brick, C., \& Yehuda, R. (2014). Resilience definitions, theory, and challenges: Interdisciplinary perspectives. $\begin{array}{llll}\text { European Journal of Psychotraumatology, } & 5(1), & 25338 .\end{array}$ https://doi.org/10.3402/ejpt.v5.25338

[8] Vibriyanti,Desinta dkk.2019. Lansia Sejahtera Tanggungjawab Siapa? Jakarta: Yayasan Pustaka Obor Indonesia.

[9] Undang-Undang Dasar 1945

[10] Undang-Undang Nomor 13 Tahun 1998 tentang kesejahteraan lansia.

[11] Yasnita, Y., Suryadi, K., Budimansyah, D., \& Winataputra, U. S. (2020). Ageism and Disharmonizing: What Can Civic Education Do? Universal Journal of Educational Research, 8(2), 520-528. https://doi.org/10.13189/ujer.2020.080223

[12] Yasnita, Y., Suryadi, K., Budimansyah, D., \& Winataputra, U. S. (2017). Elderly Society in Indonesia's Socio-Cultural Structure: 2nd International Conference on Sociology Education, 808-816. https://doi.org/10.5220/000710630808 